J. Math. and Its Appl.

E-ISSN: 2579-8936

P-ISSN: 1829-605X

Vol. 14, No. 2, Desember 2017, 89-101

\title{
Pencarian Rongga Berpotensi Binding Site pada Protein dengan Menggunakan Support Vector Machine (SVM)
}

\author{
Umi Mahdiyah' \\ Universitas Nusantara PGRI Kediri, Jl Ahmad Dahlan, Mojoroto Gg I, Kota Kediri, \\ umimahdiyah@gmail.co m
}

\begin{abstract}
Abstrak
Bioinformatika merupakan ilmu multidisipliner yang melibatkan berbagai bidang ilmu. Salah satu aplikasi dari bioinformatika adalah dalam proses desain obat berbantuan komputer. Dalam desain obat berbantuan komputer salah satu langkah awal yang dibutuhkan adalah mencari suatu rongga pada protein, rongga tersebut nantinya untuk melekat suatu ligan (partikel kecil) maupun protein yang merupakan partikel dari calon obat. Dalam penelitian ini untuk pencarian rongga delakukan dengan menggunakan metode klasifikasi dengan Support Vector Machine. Hasil dari pencarian rongga dengan metode ini menunjukkan akurasi G-Mean yang cukup tinggi yaitu 0,903 atau 90,3

Katakunci: Bioinformatik a, binding site, protein, SVM
\end{abstract}

\section{Pendahuluan}

Bioinformatika merupakan ilmu multidisipliner yang melibatkan berbagai bidang ilmu, yang meliputi biologi molekuler, matematika, ilmu komputasi, kimia molekul, fisika, dan beberapa disiplin ilmu lainnya [8]. Selama ini, bioinformatika banyak diaplikasikan dalam berbagai masalah, salah satunya adalah masalah desain obat. Dalam desain obat berbantuan komputer salah satu langkah awal yang dibutuhkan adalah mencari suatu rongga pada protein, rongga tersebut nantinya untuk melekat suatu ligan (partikel kecil) maupun protein yang merupakan partikel atau protein dari calon obat. 
Machine Learning sudah banyak digunakan pada data bioinformatika [6] serta menunjukkan hasil yang baik untuk prediksi binding site [7]. Penelitian bioinformatika dengan machine learning yang telah digunakan, diantaranya adalah "Fast prediction of protein-protein interaction sites based on Extreme Learning Machines" adalah penelitian yang dilakukan Debby D. Wang dkk[9]. Dalam paper tersebut dilakukan pencarian rongga pada permukaan protein sebagai tempat melekat protein yang lain. Selanjutnya, "Protein Sequence Classification Using Extreme Learning Machine" merupakan penelitian yang dilakukan oleh Dianhui Wang dan Guang-Bin Huang [10], penelitian tersebut mengklasifikasikan sequence protein dengan Extreme Learning Machine.

Support Vector Machine merupakan salah satu machine learning yang bagus. SVM adalah metode learning machine yang bekerja atas prinsip Structural Risk Minimization (SRM) dengan tujuan menemukan hyperplane terbaik yang memisahkan dua buah class pada input space, sehingga SVM ini dapat melihat atau mentransformasi suatu objek ke dimensi yang lebih tinggi.

Prediksi dari binding site dapat dirumuskan sebagai masalah klasifikasi biner, yaitu untuk membedakan lokasi binding site dan bukan binding site. Sehingga dalam penelitian ini digunakan SVM sebagai algoritma klasifikasi untuk pencarian binding site pada suatu protein.

\section{TINJAUAN PUSTAKA}

\subsection{Protein}

Protein adalah salah satu bio-makromolekul yang penting peranannya dalam makhluk hidup. Protein tersusun dari 20 macam asam amino alami. Asam amino penyusun protein mengandung beberapa atom kimia seperti carbon $(\mathrm{C})$, nitrogen $(\mathrm{N})$, dan hidrogen $(\mathrm{H})$, kecuali cyteine dan methionine juga mengandung sulfur (S).

Konsep desain obat pada bioinformatika didasarkan pada fungsionalitas dari protein, yaitu pencarian sebuah senyawa untuk mengaktifkan atau 
menghambat fungsi protein target, sebab protein dapat mengekspresikan suatu informasi genetik. Sebagaimana terdapat ribuan gen di dalam inti sel, masing-masing mencirikan satu sifat nyata dari organisme, di dalam sel terdapat ribuan jenis protein yang berbeda, masing-masing membawa fungsi spesifik yang ditentukan oleh gen yang sesuai [13].

\subsection{Rongga pada Permukaan Protein (Binding Site)}

Binding site adalah bagian permukaan reseptor (protein) yang berfungsi untuk melekatnya suatu obat. Binding site protein-ligan umumnya berada di pocket (celah, galur) pada permukaan protein[4]. Penentuan pocket merupakan langkah penting menuju desain obat dalam penemuan senyawa baru.

\subsection{Support Vector Machine (SVM)}

Support Vector Machine (SVM) pertama kali diperkenalkan oleh Vapnik pada tahun 1992 sebagai rangkaian harmonis konsep-konsep unggulan dalam bidang pattern recognition. Sebagai salah satu metode pattern recognition, usia SVM terbilang masih relatif muda. Walaupun demikian, evaluasi kemampuannya dalam berbagai aplikasinya menempatkannya sebagai state of the art dalam pattern recognition, dan dewasa ini merupakan salah satu tema yang berkembang dengan pesat. SVM adalah metode learning machine yang bekerja atas prinsip Structural Risk Minimization (SRM) dengan tujuan menemukan hyperplane terbaik yang memisahkan dua buah class pada input space, usaha untuk mencari lokasi hyperplane ini merupakan inti dari proses pembelajaran pada SVM. [5]

Data yang tersedia dinotasikan sebagai $\vec{x} \in \mathfrak{R}^{d}$ sedangkan label masingmasing dinotasikan $y_{i} \in\{-1,+1\}$ untuk $i=1,2, \ldots, l$, yang mana $l$ adalah banyaknya data. Diasumsikan kedua class -1 dan +1 dapat terpisah sempurna oleh hyperplane berdimensi d, yang didefinisikan

$$
\bar{w} \bar{x}+b=0
$$


Pattern $\bar{x}_{i}$ yang termasuk class -1 dapat dirumuskan sebagai pattern yang memenuhi pertidaksamaan

$$
\bar{w} \bar{x}+b \leq-1
$$

Sedangkan pattern $\bar{x}_{i}$ yang termasuk class +1

$$
\bar{w} \bar{x}+b \geq-1
$$

Margin terbesar dapat ditemukan dengan memaksimalkan nilai jarak antara hyperplane dan titik terdekatnya, yaitu $1 /\|\bar{w}\|$. Hal ini dapat dirumuskan sebagai Quadratic Programming (QP) problem, yaitu mencari titik minimal, dengan memperhatikan .

$$
\begin{aligned}
& \min _{\bar{w}} \tau(w)=\frac{1}{2}\|\bar{w}\|^{2} \\
& y_{i}\left(\bar{x}_{i} \cdot w+b\right)-1 \geq 0, \forall i
\end{aligned}
$$

Problem ini dapat dipecahkan dengan berbagai teknik komputasi, di antaranya Lagrange Multiplier.

$$
\begin{gathered}
L(\bar{w}, b, \alpha)=\frac{1}{2}\|\bar{w}\|^{2}-\sum_{i=1}^{l} \alpha_{i}\left(y_{i}\left(\left(\bar{x}_{i} \cdot \bar{w}+b\right)-1\right)\right) \\
(i=1,2, \ldots, l)
\end{gathered}
$$

$\alpha_{i}$ adalah Lagrange multipliers, yang bernilai nol atau positif $\left(a_{i} \geq 0\right)$. Nilai optimal dari persamaan di atas dapat dihitung dengan meminimalkan $L$ terhadap $\bar{w}$ dan $b$,dan memaksimalkan $L$ terhadap $\alpha_{i}$. Dengan memperhatikan sifat bahwa pada titik optimal gradient $L=0$, persamaan di atas dapat dimodifikasi sebagai maksimalisasi problem yang hanya mengandung $\alpha$ saja, sebagaimana persamaan (6).

$$
\sum_{I=1}^{L} \alpha_{i}-\frac{1}{2} \sum_{i, j=1}^{l} \alpha_{i} \alpha_{j} y_{i} y_{j} \bar{x}_{i} \bar{x}_{j}
$$

\section{Dengan}

$$
\alpha_{i} \geq 0(i=1,2 . .)
$$




$$
\sum_{i=1}^{l} \alpha_{i} y_{i}=0
$$

Dari hasil dari perhitungan ini diperoleh $a_{i}$ yang kebanyakan bernilai positif. Data yang berkorelasi dengan $a_{i}$ yang positif inilah yang disebut sebagai support vector.[1]

\section{Metode Penelitian}

\subsection{Pengambilan Data}

Data yang digunakan dalam penelitian ini merupakan data eksperimental, yaitu data protein yang didapat dari webserver RCSB Protein Data Bank. Selanjutnya dari data PDB dicari nilai setiap atributnya dengan menggunakan program online LISE[11]. Dalam program LISE tersebut dapat diperoleh 2 atribut atau variabel, yaitu nilai score conservation dan nilai potential energy. 3.2 Data dan Pembagian Data

Data yang digunakan dalam penelitian ini dapat dilihat pada Tabel 1.

Tabel 1 Data Protein berdasarkan jenisnya

\begin{tabular}{|c|c|c|c|}
\hline No & Protein ID & Banyak Data + & Banyak Data - \\
\hline 1 & 4TPI & 776 & 2266 \\
\hline 2 & 2ZAL & 688 & 4598 \\
\hline 3 & 2 V8L & 1030 & 1030 \\
\hline 4 & $1 \mathrm{WYW}$ & 827 & 8789 \\
\hline 5 & $1 \mathrm{RN} 8$ & 918 & 1315 \\
\hline 6 & $1 \mathrm{C} 1 \mathrm{P}$ & 704 & 4093 \\
\hline 7 & 3D4P & 988 & 5216 \\
\hline 8 & $1 \mathrm{~A} 4 \mathrm{U}$ & 737 & 3926 \\
\hline 9 & $2 \mathrm{WLA}$ & 846 & 1598 \\
\hline 10 & 2GGA & 316 & 3830 \\
\hline 11 & $1 \mathrm{SQF}$ & 934 & 3431 \\
\hline 12 & $1 \mathrm{O} 26$ & 1332 & 7940 \\
\hline 13 & $1 \mathrm{G} 6 \mathrm{C}$ & 724 & 3780 \\
\hline 14 & $1 \mathrm{BJ} 4$ & 477 & 3728 \\
\hline 15 & $1 \mathrm{U} 7 \mathrm{C}$ & 731 & 5413 \\
\hline 16 & $1 \mathrm{ADE}$ & 805 & 8267 \\
\hline
\end{tabular}

Untuk membagi data training dan data testing dalam penelitian ini digunakan 5-fold cross validation artinya $80 \%$ data untuk training dan $20 \%$ testing. 


\subsection{Alur Penelitian}

Alur penelitian ini dapat dilihat pada Gambar 1.

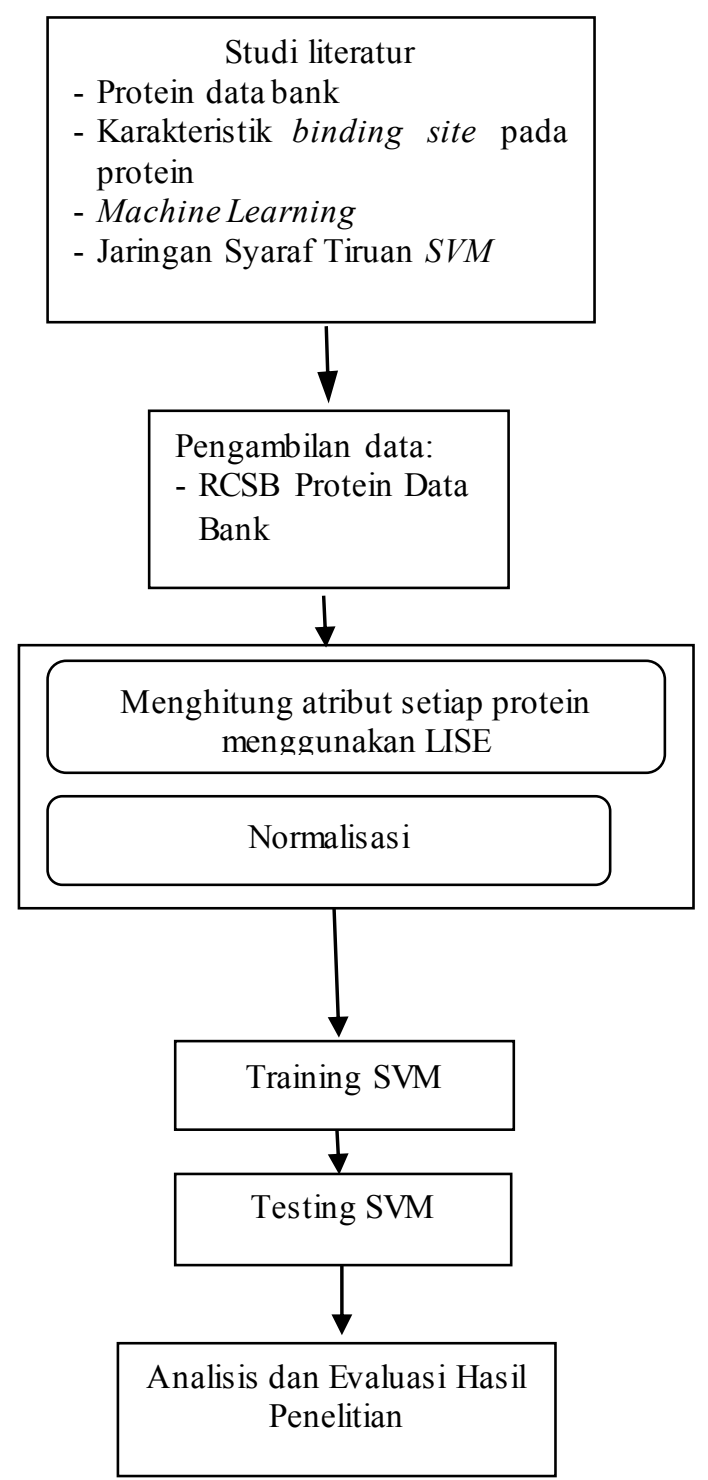

Gambar 1 Alur Penelitian

Studi literatur tentang Protein data bank, karakteristik binding site pada protein, Machine Learning, Jaringan Syaraf Tiruan SVM, dilakukan untuk memahami tenang protein, binding site, dan SVM. Setelah itu, dilakukan pengambilan data protein pada web RCSB Protein Data Bank. Selanjutnya atribut yang dibutuhkan untuk klasifikasi didapat pada web LISE dengan menginputkan protein ID atau mengupload file .pdb yang diperoleh sebelumnya. 
Data dengan atributnya yang diperoleh dari LISE dinormalisasi dengan normalisasi minmax. [12]

$$
x_{\text {normalized }}=\left(\frac{x-x_{\min }}{x_{\max }-x_{\min }} \times\left(\max _{\text {new }}-\min _{\text {new }}\right)\right)+\min _{\text {new }}
$$

Selanjutnya dari data yang ada dilakukan 5-fold cross validation untuk dilakukan training dan testing, kemudian dianalisis. Untuk mengukur performa dari klasifikasi data pengujian imbalance dalam hal ini digunakan confusion matrix, precision dan recall, specificity, dan G-mean[3]. Tabel confusion matrix Dapat dilihat pada tabel 2, sedangkan untuk pengukuran performa seperti pada Persamaan 8 sampai persamaan 11 .

Tabel 2. Confusion Matrix

\begin{tabular}{|c|c|c|c|}
\cline { 3 - 4 } \multicolumn{2}{c|}{} & \multicolumn{2}{c|}{ Nilai Sebenarnya } \\
\cline { 3 - 4 } \multicolumn{2}{c|}{} & True & False \\
\hline \multirow{3}{*}{ Prediksi } & True & $\begin{array}{c}\text { TP } \\
\text { (True Positive) }\end{array}$ & $\begin{array}{c}\text { FP } \\
\text { (False Positive) }\end{array}$ \\
\cline { 2 - 4 } & False & FN & TN \\
& & (False Negative) & (True Negative) \\
\hline
\end{tabular}

Precision adalah presentase dari data yang diprediksi benar oleh classifier yang bernilai benar.

$$
\text { precision }=\frac{T P}{T P+F P} .
$$

Recall adalah porsi dari data sampel yang diprediksi benar oleh classifier.

$$
\begin{aligned}
& \text { recall }=\frac{T P}{T P+F N} . \\
& \text { sensitifity=recall }
\end{aligned}
$$

Geometric mean telah digunakan beberapa peneliti untuk mengevaluasi classifier pada dataset yang imbalanced . G-mean mengindikasikan keseimbangan antara kinerja klasifikasi pada kelas mayoritas dan minoritas. Ukuran G-mean diambil berdasarkan sensitifity (akurasi dari data positif) dan specificity (akurasi data negatif). [3] 


$$
\begin{aligned}
& \text { specificity }=1-\frac{T P}{F P+T N} \\
& G-\text { mean }=\sqrt{\text { sensitivity } \times \text { specificity }}
\end{aligned}
$$

\section{Hasil dan Pembahasan}

Dalam penelitian ini, data yang digunakan merupakan data data protein hasil eksperimen yang dipublish dalam web RCSB Protein data bank, yang juga merupakan data open source. Data protein dengan binding site nya adalah data yang mempunyai karakter imbalance, sehingga untuk mengkur performa algoritma yang digunakan untuk klasifikasi tidak dapat menggunakan perhitungan akurasi biasa. Dalam penelitian ini ukuran performa dilihat dari precision, recall, specificity, dan G-mean. Hasil dari penelitian ini dapat dilihat pada Tabel 3, sedangkan grafik dari hasil penelitian dapat dilihat pada Gambar 2.

Tabel 3. Hasil Penelitian

\begin{tabular}{|c|c|c|c|c|c|c|}
\hline \multirow{2}{*}{$\begin{array}{c}\text { Protein } \\
\text { ID }\end{array}$} & \multicolumn{5}{|c|}{ Nilai } \\
\cline { 2 - 7 } & Precision & Recall & Specificity & G-mean & $\begin{array}{c}\text { CPU Time } \\
\text { (Training) }\end{array}$ & $\begin{array}{c}\text { CPU Time } \\
\text { (Testing) }\end{array}$ \\
\hline 1A4U & 0.9586 & 0.87585 & 0.9741 & 0.92369 & 12.090 & 0.0676 \\
\hline 1ADE & 0.9063 & 0.85934 & 0.9312 & 0.89453 & 146.014 & 0.0546 \\
\hline 1BJ4 & 0.5756 & 0.81289 & 0.5452 & 0.66572 & 19.032 & 0.0312 \\
\hline 1C1P & 0.9809 & 0.96076 & 0.9844 & 0.97249 & 10.816 & 0.0546 \\
\hline 1G6C & 0.9930 & 0.96616 & 0.9981 & 0.98202 & 18.876 & 0.0585 \\
\hline 1O26 & 0.8036 & 0.93525 & 0.7815 & 0.85493 & 18.447 & 0.0520 \\
\hline 1RN8 & 0.9777 & 0.97222 & 0.9815 & 0.9765 & 11.050 & 0.0338 \\
\hline 1SQF & 0.9420 & 0.81263 & 0.9772 & 0.89111 & 13.416 & 0.0546 \\
\hline 1U7Z & 0.9971 & 0.97538 & 10.000 & 0.98761 & 17.940 & 0.0832 \\
\hline 1WYW & 0.4497 & 0.98864 & 0.3991 & 0.62814 & 12.610 & 0.0754 \\
\hline 2GGA & 0.9890 & 0.96756 & 0.9907 & 0.97908 & 19.071 & 0.1755 \\
\hline 2V8L & 0.9690 & 0.98026 & 0.9578 & 0.96895 & 11.128 & 0.1170 \\
\hline 2WLA & 0.9970 & 0.97674 & 10.000 & 0.9883 & 12.948 & 0.0364 \\
\hline 2ZAL & 0.9949 & 0.96076 & 10.000 & 0.98018 & 12.766 & 0.0442 \\
\hline 3D4P & 0.9794 & 0.87247 & 0.9996 & 0.93388 & 58.656 & 0.0936 \\
\hline
\end{tabular}




\begin{tabular}{|c|c|c|c|c|c|c|}
\hline \multirow{2}{*}{$\begin{array}{c}\text { Protein } \\
\text { ID }\end{array}$} & \multicolumn{6}{|c|}{ Nilai } \\
\cline { 2 - 7 } & Precision & Recall & Specificity & G-mean & $\begin{array}{c}\text { CPU Time } \\
\text { (Training) }\end{array}$ & $\begin{array}{c}\text { CPU Time } \\
\text { (Testing) }\end{array}$ \\
\hline 4TPI & 0.7073 & 0.98174 & 0.6133 & 0.77593 & 10.764 & 0.1326 \\
\hline $\begin{array}{c}\text { Rata- } \\
\text { rata }\end{array}$ & $\mathbf{0 . 8 9 1 9 5 9}$ & $\mathbf{0 . 9 3 3 1 1}$ & $\mathbf{0 . 8 8 6 6}$ & $\mathbf{0 . 9 0 3 2}$ & $\mathbf{2 . 4 4 4 3}$ & $\mathbf{0 . 0 7 8 4}$ \\
\hline
\end{tabular}

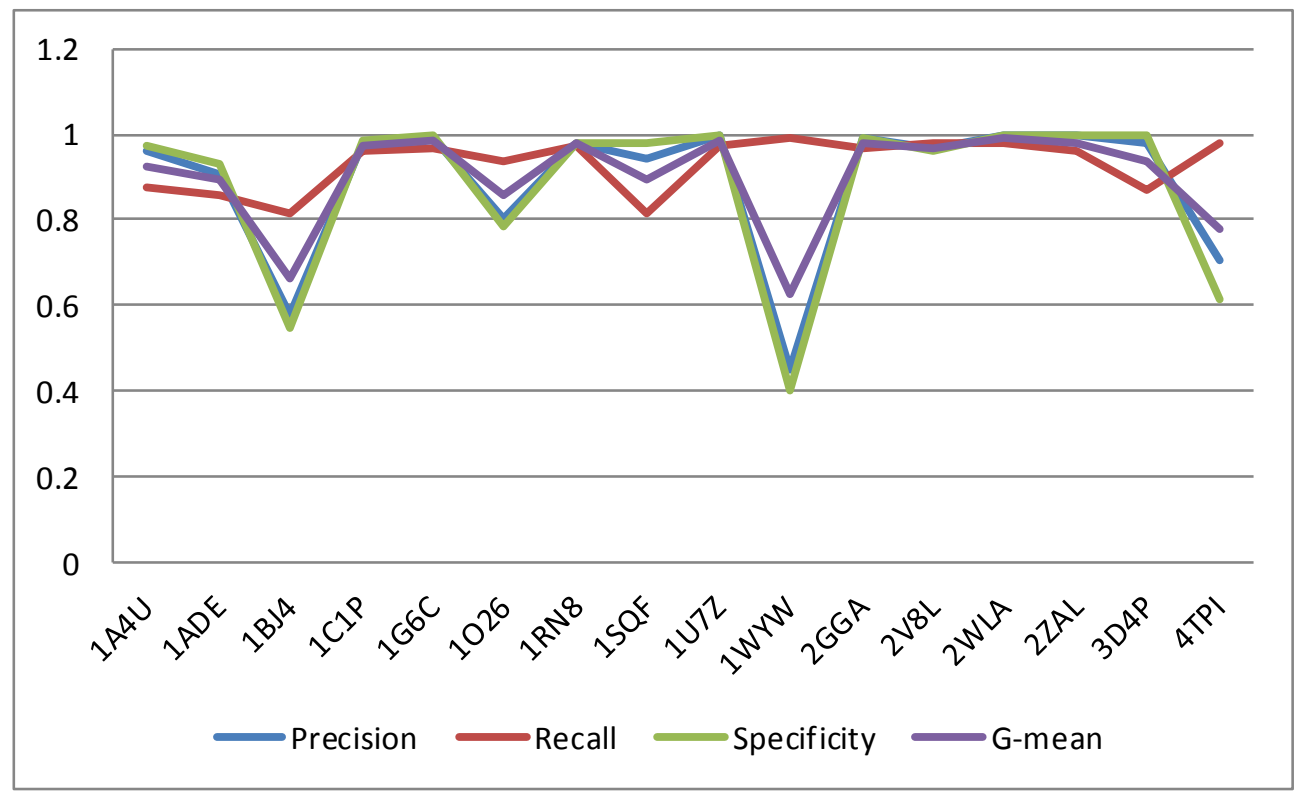

Gambar 2. Grafik hasil penelitian

Dari tabel dan grafik di atas dapat dilihat bahwa pencarian rongga pada protein dengan metode klasifikasi menggunakan Support Vector Machine mempunyai nilai akurasi yang cukup tinggi. Hal tersebut dapat dilihat bahwa rata-rata dari hasil pengukuran akurasi, hampir di semua data protein mempunyai akurasi baik precision, recall, specificity, maupun G-Mean lebih dari $60 \%$ atau 0,6 .

Precision dari pencarian rongga pada protein dengan metode klasifikasi menggunakan Support Vector Machine memiliki rata-rata 0.891959. Recall, specificity, dan G-Mean memiliki rata-rata berturut turut 0.93311, 0.8866, 0.9032 .

Pada Gambar 2 dapat dilihat bahwa pada beberapa protein memiliki perbedaan akurasi yang sangat signifikan. Berdasarkan pengamatan terhadap 
jenis nya hal tersebut terjadi karena data yang diambil dan pembagian data training serta testing dalam penelitian ini tidak memperhatikan jenis proteinnya. Sehingga untuk data training dan data testing di beberapa kasus dilakukan training dan testing untuk jenis protein yang berbeda.

\subsection{Tampilan Program}

Gambar 2 merupakan tampilan dari program untuk pencarian rongga pada permukaan protein secara 3 dimensi atau dilihat dari sumbu $x, y, z$. Warna hijau menunjukkan permukaa protein, sedangkan warna biru menunjukkan lokasi rongga tersebut. Sebelah kanan (actual binding site) merupakan gambar asli dari protein dan rongganya, sedangkan sebelah kiri (predicting binding site) merupakan hasil pencarian dengan klasifikasi SVM.

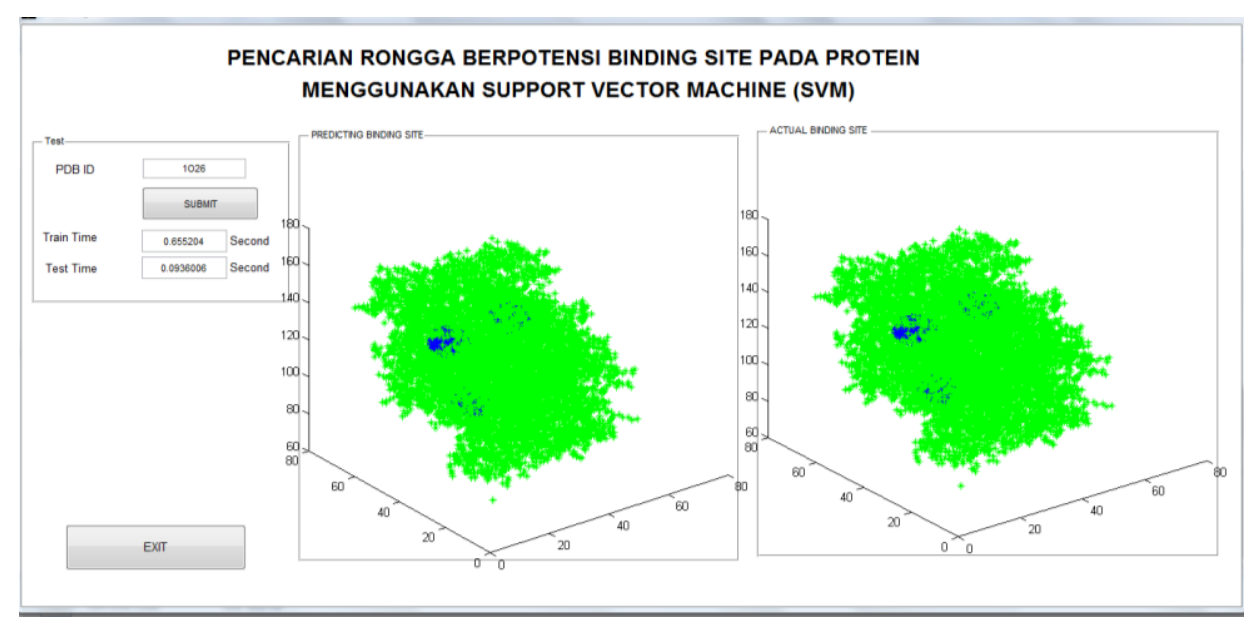

Gambar 3. Tampilan Program dengan contoh running protein ID 1026

Gambar 4 merupakan tampilan protein dan rongganya dilihat secara dua dimensi dari sumbu $\mathrm{x}$ dan $\mathrm{y}$. Dari gambar tersebut dapat dilihat bahwa hanya terdapat 2 rongga pada permukaan protein 1O26. Sedangkan pada Gambar 5 jika dilihar dari sumbu $\mathrm{x}-\mathrm{z}$ terlihar terdapat 3 rongga protein. 

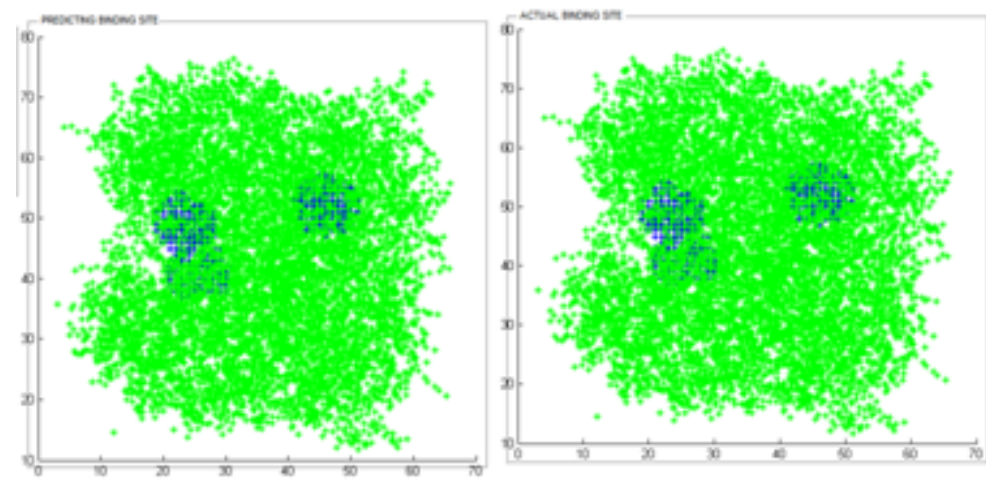

Gambar 4. Tampilan protein dilihat secara 2 dimensi dari sumbu $\mathrm{x}-\mathrm{y}$
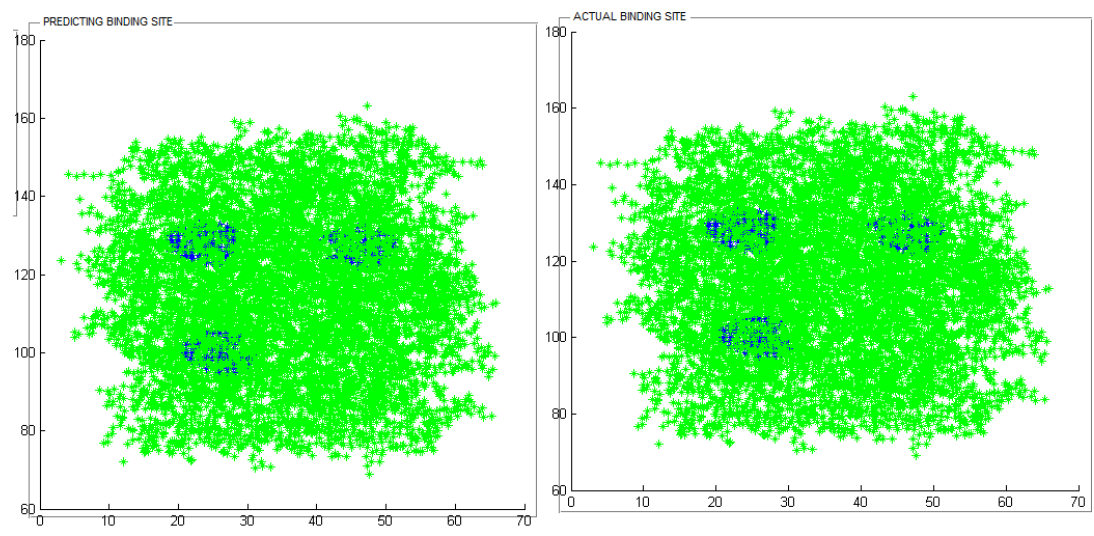

Gambar 5. Tampilan protein dilihat secara 2 dimensi dari sumbu $\mathrm{x}-\mathrm{Z}$

\section{Kesimpulan}

Dari paparan hasil penelitian dan analisis data dapat dilihat bahwa SVM memiliki akurasi yang tinggi jika diaplikasikan untuk pencarian rongga pada permukaan protein. Rata-rata dari Precision, Recall, specificity, dan G-Mean memiliki rata-rata berturut turut $0.891959,0.93311,0.8866,0.9032$.

Dalam penelitian ini juga dapat dilihat bahwa untuk klasifikasi data protein harus diperhatikan berdasarkan jenis-jenisnya. Tidak semua data dapat digunakan data latih/training untuk keseluruhan protein

\section{$6 \quad$ Pustaka}

[1] Batuwitage, Manohara Rukshan Kannangara, "Enhanced Class Imbalance Learning Methods for Support Vector Machines”, Thesis of Doctor of Philosophy Hilary Term 2010, St. Cross College, 2010. 
[2] Bekkar, Mohamed, dan Taklit Akrouf Alitouche, "Imbalanced Data Learning Approaches Review”, International Journal of Data Mining \& Knowledge Management Process (IJDKP), Vol. 4, No. 4, hal. 15-33, 2013.

[3] H. He, E.A. Garcia, "Learning from imbalanced data". IEEE Trans. Knowl. Data Eng, Vol. 21, no.9, hal. 1263-1284,2009.

[4] Hendlich, Manfred, Rippmann, Friedrich dan Gerhard Barnickel, "LIGSITE: Automatic and efficient detection of potential small molecule-binding sites in proteins", Journal of Molecular Graphics and Modelling, Vol.15, hal. 359 -363, , (1997),

[5] Nugroho, SA, Witarto, AB, Handoko, D, "Application of Support Vector Machine in Bioinformatics", Proceeding of Indonesian Scientific Meeting in Central Japan, December 20, 2003.

[6] Mahdiyah, Umi, Irawan, Isa, dan Imah,EM, "Study Comparison Backpropogation, Support Vector Machine, and Extreme Learning Machine for Bioinformatics Data”, Journal of Computer Science and Information, Vol 8: No 1, 53-59, 2015a.

[7] Mahdiyah, Umi, Imah,EM, dan Irawan, "Integrating Data Selection and Extreme Learning Machine to Predict Protein-Ligand Binding Site”, Contemporary Engineering Sciences, Vol. 9, no. 16, 791 797,2016.

[8] Shen, Shiyi dan Jack A. Tuszynski, Theory and Mathematical Methods for Bioformatics, Springer, Verlag Berlin Heidelberg, 2008.

[9] Wang, Debby D., Wang, Ran dan Hong Yan, "Fast prediction of protein-protein interaction sites based on Extreme Learning Machines”, Neurocomputing,Vol. 128, hal. 258-266, 2014.

[10] Wang, Dianhui dan Guang-Bin Huang, "Protein Sequence Classification Using Extreme Learning Machine”, Proceedings of International Joint Conference on Neural Networks, Montreal, Canada,hal. 1406-1411, 2005. 
[11] Xie, Z.R. and Hwang, M.J. (2012) Ligand-binding site prediction using ligand-interacting and binding site-enriched protein triangles. Bioinformatics, 28, 1579-1585.

[12] Zhu, Chengzhang, Yin, Jianping dan Qian Li, "A Stock Decision Support System Based on ELM", Proceedings of the International Conference on Extreme Learning Machines (ELM2013), (eds) Sun, F., Toh, K.-A., Romay, M.G., Mao, K., Beijing, hal.67-79, 2013.

[13] Zvelebil, Marketa dan Jeremy O. Baum, "Understanding Bioinformatics", Garland Science, New York, 2008. 